\title{
The nitrogen isotope effect of benthic remineralization-nitrification-denitrification coupling in an estuarine environment
}

\author{
M. Alkhatib ${ }^{1,3}$, M. F. Lehmann ${ }^{2}$, and P. A. del Giorgio ${ }^{3}$ \\ ${ }^{1}$ Geochemistry and Geodynamics Research Center (GEOTOP-UQAM-McGill), University of Quebec at Montreal, Montreal, \\ H3C 3P8 Quebec, Canada \\ ${ }^{2}$ Department of Environmental Science, Bernoullistrasse 30, University of Basel, 4056 Basel, Switzerland \\ ${ }^{3}$ Département des sciences biologiques, Université du Québec à Montréal (UQAM), C.P. 8888, succ. Centre-Ville, \\ Montréal, Québec, Canada
}

Correspondence to: M. F. Lehmann (moritz.lehmann@unibas.ch)

Received: 14 November 2011 - Published in Biogeosciences Discuss.: 8 December 2011

Revised: 2 April 2012 - Accepted: 10 April 2012 - Published: 4 May 2012

\begin{abstract}
The nitrogen (N) stable isotopic composition of pore water nitrate and total dissolved $\mathrm{N}$ (TDN) was measured in sediments of the St. Lawrence Estuary and the Gulf of St. Lawrence. The study area is characterized by gradients in organic matter reactivity, bottom water oxygen concentrations, as well as benthic respiration rates. $\mathrm{N}$ isotope effects on the water column associated with the benthic exchange of nitrate $\left(\varepsilon_{\mathrm{app}}\right)$ and TDN $\left(\varepsilon_{\mathrm{sed}}\right)$ during benthic nitrification-denitrification coupling were investigated. The sediments were a major sink for nitrate and a source of reduced dissolved $\mathrm{N}\left(\mathrm{RDN}=\mathrm{DON}+\mathrm{NH}_{4}^{+}\right)$. We observed that both the pore water nitrate and RDN pools were enriched in ${ }^{15} \mathrm{~N}$ relative to the water column, with increasing $\delta^{15} \mathrm{~N}$ downcore in the sediments. As in other marine environments, the biological nitrate isotope fractionation of net fixed $\mathrm{N}$ loss was barely expressed at the scale of sediment-water exchange, with $\varepsilon_{\text {app }}$ values $<3 \%$. The strongest under-expression (i.e. lowest $\varepsilon_{\text {app }}$ ) of the biological $\mathrm{N}$ isotope fractionation was observed at the most oxygenated sites with the least reactive organic matter, indicating that, through their control on the depth of the denitrification zone, bottom water oxygen concentrations and the organic matter reactivity can modulate $\varepsilon_{\text {app. }}$. For the first time, actual measurements of $\delta^{15} \mathrm{~N}$ of pore water RDN were included in the calculations of $\varepsilon_{\text {sed }}$. We argue that large fractions of the sea-floor-derived DON are reactive and, hence, involved in the development of the $\delta^{15} \mathrm{~N}$ of dissolved inorganic N (DIN) in the water column. In the
\end{abstract}

St. Lawrence sediments, the combined benthic $\mathrm{N}$ transformations yield a flux of ${ }^{15} \mathrm{~N}$-enriched RDN that can significantly elevate $\varepsilon_{\text {sed }}$ above $\varepsilon_{\text {app }}$. Calculated $\varepsilon_{\text {sed }}$ values were within the range of $4.6 \pm 2 \% \circ$ and were related to organic matter reactivity and oxygen penetration depth in the sediments. $\varepsilon_{\text {sed }}$ reflects the $\delta^{15} \mathrm{~N}$ of the $\mathrm{N}_{2}$ lost from marine sediments and thus best describes the isotopic impact of fixed $\mathrm{N}$ loss from sediments on the oceanic fixed $\mathrm{N}$ pool. Our mean value for $\varepsilon_{\text {sed }}$ is larger than assumed by earlier work, questioning current ideas with regards to the state of balance of the modern $\mathrm{N}$ budget.

\section{Introduction}

Nitrogen $(\mathrm{N})$ plays a critical role as a nutrient in marine systems (Rabalais et al., 2002). Fixed $\mathrm{N}$ is mainly removed from the ocean by conversion to $\mathrm{N}_{2}$ by denitrification and/or anammox (Strous et al., 1999; Zehr and Ward, 2002; Brandes and Devol, 2002; Hulth et al., 2005). Loss by suboxic $\mathrm{N}_{2}$ production occurs in the absence of dissolved oxygen (DO), in the global ocean oxygen-deficient zones, and, more importantly, in marine sediments. Previous work has demonstrated that benthic denitrification in continental shelf sediments is by far the largest sink of oceanic N, accounting for up to $\sim 70 \%$ of the total global denitrification (Middelburg et al., 1996; Codispoti et al., 2001; Brandes and Devol, 
2002). However, benthic $\mathrm{N}$ elimination in pelagic sediments can also drive basin-wide nitrate deficits (Sigman et al., 2003; Lehmann et al., 2005). During early sedimentary diagenesis, particulate organic N (PON) is hydrolyzed to dissolved organic nitrogen (DON) by bacterial hydrolytic enzymes, and a large fraction of this DON is ultimately remineralized to ammonium (Fig. 1). Both the DON and $\mathrm{NH}_{4}^{+}$can diffuse to the overlying bottom water, but in the presence of $\mathrm{O}_{2}$, a portion of the regenerated $\mathrm{NH}_{4}^{+}$is oxidized to $\mathrm{NO}_{3}^{-}$(nitrification) before it can escape from the sediments. This $\mathrm{NO}_{3}^{-}$ may, in turn, be used as a terminal electron acceptor by denitrifying bacteria producing gaseous forms of $\mathrm{N}$ (coupled nitrification-denitrification). Rates and occurrence of diagenetic $\mathrm{N}$-cycle reactions are influenced by substrate availability, organic matter reactivity, and redox conditions (Lehmann et al., 2007; Thibodeau et al., 2010).

Given that the $\mathrm{N}$-isotope effects of specific N-loss terms are known, the isotopic composition of the marine fixed $\mathrm{N}$ pool can be used to constrain regional or global $\mathrm{N}$ fluxes (Sigman et al., 2003; Brandes and Devol, 2002; Lehmann et al., 2005). The preferential consumption of ${ }^{14} \mathrm{NO}_{3}^{-}$by denitrifying bacteria causes the remaining $\mathrm{NO}_{3}^{-}$pool to become progressively enriched in ${ }^{15} \mathrm{~N}$ (Cline and Kaplan, 1975; Mariotti et al., 1981). Hence, around suboxic water masses, $\delta^{15} \mathrm{~N}$ $\mathrm{NO}_{3}^{-}$is significantly elevated with respect to the mean ocean value of 5\%o (Liu and Kaplan, 1989; Voss et al., 2001; Sigman et al., 2003). In agreement with higher estimates of the organism-level $\mathrm{N}$ isotope effect for denitrifiers in cultures (Granger et al., 2008), $\mathrm{N}$ isotope effects $\left(\varepsilon_{\text {cell }}\right)$ observed in natural environments range between $20 \%$ and $30 \%$ (Fig. 1). In contrast, the nitrate $\mathrm{N}$ isotope effect of benthic denitrification at the scale of sediment-water exchange $\left(\varepsilon_{\text {app }}\right)$ has been proposed to be significantly less than $\varepsilon_{\text {cell }}$ if denitrification is limited by the rate of diffusive nitrate supply to the active denitrification sites within the sediments (Brandes and Devol, 1997; Lehmann et al., 2004, 2007; see illustration in Fig. 1). Moreover, it has been shown that such suppression of the biological $\mathrm{N}$ isotope effect of denitrification due to diffusion limitation applies to both reactive coastal sediments and less reactive pelagic sediments (Brandes and Devol, 1997; Lehmann et al., 2004, 2007), yet possibly at different degrees.

The use of marine nitrate $\delta^{15} \mathrm{~N}$ as tracer of sedimentary versus water column denitrification is dependent on the knowledge of the total, or net, sedimentary $\mathrm{N}$ isotope effect. Model simulations by Lehmann et al. (2007) suggest that differences in sediment reactivity and the oxygen concentration of the overlying water have a significant effect on the geometry of the oxic layer and the denitrification zone, and thus on the expression of the biological $\mathrm{N}$-isotope effect of denitrification in the water column. An important point considered by previous work, but not directly addressed using measured data, is the potential contribution of dissolved $\mathrm{N}$-forms other than nitrate (i.e. ammonium and DON) to the overall
$\mathrm{N}$ isotope effect of benthic $\mathrm{N}$-cycling. Thus far, ammonium and DON fluxes out of the sediments have not been investigated in terms of their $\mathrm{N}$-isotopic composition. Based on model simulations, Lehmann et al. (2007) argued that partial nitrification may, while generating ${ }^{15} \mathrm{~N}$-depleted nitrate within the pore water DIN pool, produce pore water ammonium that is strongly enriched in ${ }^{15} \mathrm{~N}$. If this ammonium escapes to the water column, it can shunt significant amounts of "heavy" fixed $\mathrm{N}$ to the water column, an aspect that has until today been neglected in global or regional $\mathrm{N}$ isotope balances. Moreover, DON effluxing from sediments has a high potential to be remineralized in the overlying water, and as a result may impact the isotopic composition of the DIN pool in the water column as well. It is important to understand that ultimately it is the combined net flux of $\mathrm{N}$, including the sediment water exchange of reduced dissolved $\mathrm{N}$ species (i.e., $\mathrm{RDN}=\mathrm{NH}_{4}^{+}+\mathrm{DON}$ ) that is pertinent to the understanding of the isotopic impact of benthic $\mathrm{N}$ elimination on the water column of a marine environment. This combined effect (referred to as $\varepsilon_{\text {sed }}$, as introduced by Lehmann et al., 2007) has been posited to vary as a function of environmental conditions and sediment characteristics.

Here we present high-resolution profiles of the concentration and $\mathrm{N}$ isotopic composition of pore water nitrate and total dissolved nitrogen $\left(\mathrm{TDN}=\mathrm{NO}_{\mathrm{x}}+\mathrm{RDN}\right)$ from several locations along the Laurentian Channel. The objective of this study was to assess the $\mathrm{N}$ isotope effect of benthic $\mathrm{N}$ cycling on the water column fixed $\mathrm{N}$ pool in the estuary. Our study explores, for the first time based on observational data, the impact of benthic-pelagic exchange of dissolved reduced $\mathrm{N}$ compounds (i.e. RDN). The Laurentian Channel of the St. Lawrence Estuary displays pronounced spatial gradients with respect to benthic DIN fluxes, sediment organic matter $(\mathrm{OM})$ reactivity, and degradation state, as well as bottom water oxygenation (Lehmann et al., 2009; Thibodeau et al., 2010; Alkhatib et al., 2012a). Hence, it is an interesting environment to study possible links between $\varepsilon_{\text {app }}, \varepsilon_{\text {sed }}$, and these spatial geochemical changes, testing previous hypotheses on the environmental controls on benthic dissolved $\mathrm{N}$ isotope effects.

\section{Material and methods}

\subsection{Study site and sampling}

The Laurentian Channel (Fig. 2) displays pronounced spatial variations in $\mathrm{OM}$ source, water column depth, surface water productivity, and water column DO concentration (Table 1; Alkhatib et al., 2012a, and references therein). DO concentration measurements along the Laurentian Channel revealed the presence of year-round hypoxic bottom waters covering approximately $1300 \mathrm{~km}^{2}$ of the Lower Estuary sea floor, with [DO] as low as $\sim 50 \mu \mathrm{moll}^{-1}$ (Gilbert et al., 2005), while the bottom water [DO] in the Gulf is 


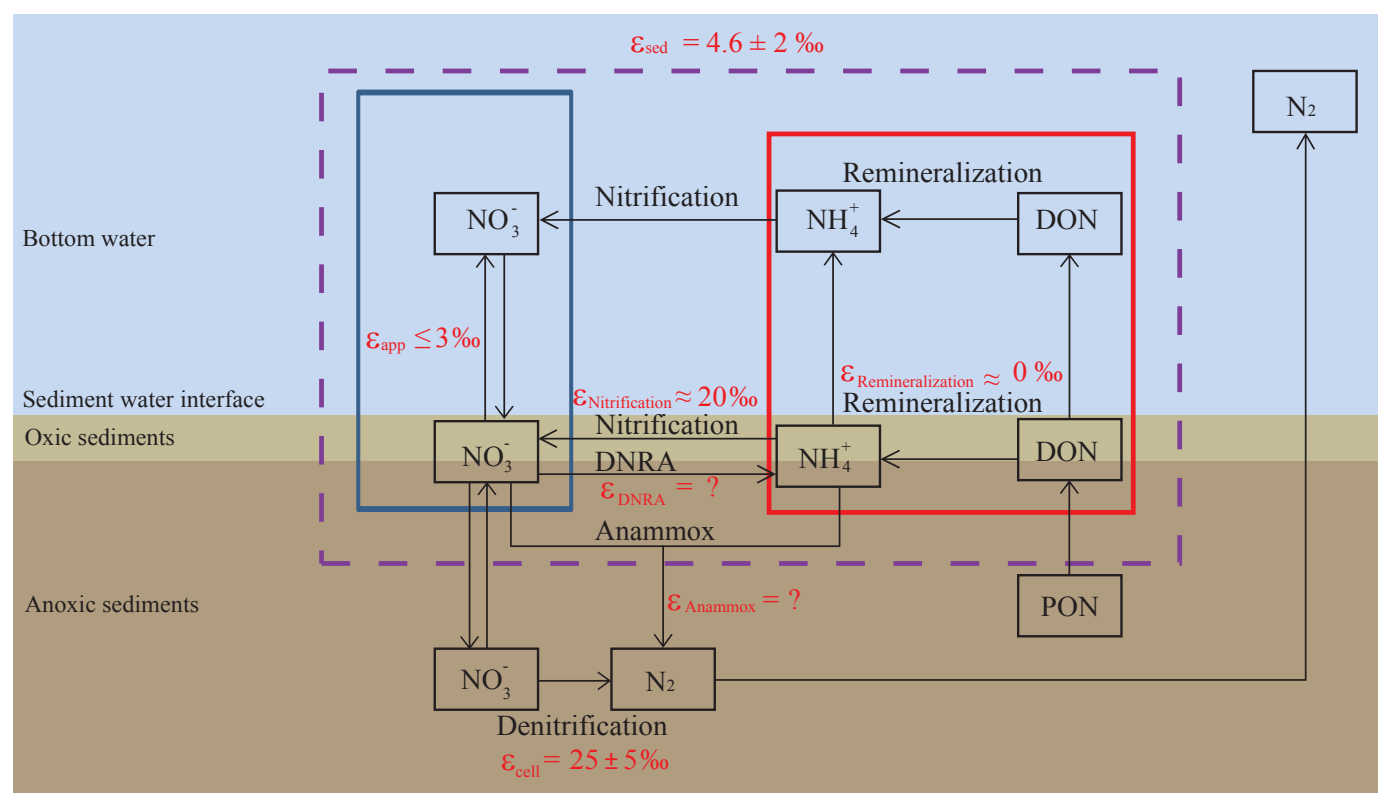

Fig. 1. Schematic overview depicting the most important processes that control benthic DIN/RDN exchange and associated $N$ isotope effects. $\varepsilon_{\text {cell }}$ refers to the biological $\mathrm{N}$ isotope effects of denitrification, $\varepsilon_{\text {app }}$ refers to the apparent nitrate $\mathrm{N}$ isotope effect of benthic nitrate reduction in the above-lying water column, and $\varepsilon_{\text {sed }}$ refers to the $\mathrm{N}$ isotope effect of total dissolved nitrogen benthic exchange, considering both nitrate and RDN fluxes (see text for details).

Table 1. Sampling site characteristics along the Laurentian Channel: depth, oxygen concentration in bottom water, oxygen penetration depth (OPD), and benthic fluxes of $\mathrm{O}_{2}$ and nitrate.

\begin{tabular}{|c|c|c|c|c|c|c|}
\hline Sta. I.D. & $\begin{array}{l}\text { Depth } \\
(\mathrm{m})\end{array}$ & $\begin{array}{c}\text { Bottom water }\left[\mathrm{O}_{2}\right]^{\mathrm{a}} \\
\left(\mu \mathrm{mol} 1^{-1}\right)\end{array}$ & $\begin{array}{l}\mathrm{OPD}^{\mathrm{b}} \\
(\mathrm{cm})\end{array}$ & $\begin{array}{c}\mathrm{O}_{2} \text { flux }^{\mathrm{a}} \\
\left(\mu \mathrm{mol} \mathrm{m} \mathrm{m}^{-2} \mathrm{~d}^{-1}\right)\end{array}$ & $\begin{array}{l}\mathrm{NO}_{3}^{-} \text {benthic flux } \\
\left(\mu \mathrm{mol} \mathrm{m} \mathrm{m}^{-2} \mathrm{~d}^{-1}\right)^{\mathrm{c}}\end{array}$ & $\begin{array}{l}\mathrm{NO}_{3}^{-} \text {diff. flux } \\
\left(\mu \mathrm{mol} \mathrm{m}{ }^{-2} \mathrm{~d}^{-1}\right)^{\mathrm{d}}\end{array}$ \\
\hline 25 & 290 & 65 & 0.64 & -6410 & -450 & -130 \\
\hline 23 & 350 & 63 & 0.92 & -4300 & -580 & -140 \\
\hline 22 & 321 & 70 & N.D. & N.D. & N.D. & -140 \\
\hline 21 & 330 & 75 & 1.64 & -3220 & -250 & -140 \\
\hline 20 & 330 & 97 & N.D. & N.D. & N.D. & -130 \\
\hline 19 & 370 & 108 & 1.82 & -3750 & N.D. & -110 \\
\hline 18 & 370 & 123 & 1.56 & -4950 & -130 & -100 \\
\hline Anticosti & 283 & 106 & 1.53 & -4360 & N.D. & -130 \\
\hline 16 & 420 & 197 & N.D. & N.D. & N.D. & 25 \\
\hline
\end{tabular}

${ }^{a}$ From Thibodeau et al. (2010). ${ }^{b}$ From Alkhatib et al. (2012a). ${ }^{\mathrm{c}}$ From ex situ incubations. ${ }^{\mathrm{d}}$ Based on concentration gradients.

$>150 \mu \mathrm{mol} \mathrm{l}^{-1}$. The sediment reactivity in the Lower Estuary and the Gulf, which we determined previously using amino acid and chlorin-based preservation indicators (DI and CI, respectively), shows a clear trend along the Laurentian Channel, with the highest OM reactivity (i.e. low CI and high DI; for definition see Table 2 caption) at the head of the Lower Estuary (Sta. 25, 23 and 22 in Fig. 2) and significantly lower OM reactivities at the Gulf stations (Alkhatib et al., 2012a).

Sediment multicores were recovered from nine stations along the Laurentian Channel during two summer 2006 cruises (June and August) aboard the R/V Coriolis II (Fig. 2) using a Bowers \& Connelly multicorer $(10 \mathrm{~cm}$ internal diameter). Immediately upon corer recovery, cores were capped without headspace, and pore water samples were collected from cores using shipboard whole core squeezing (WCS) (Bender et al., 1987). WCS is a pore water sampling technique designed for millimeter depth resolution near the sediment-water interface. Cores were kept at in situ temperature by wrapping them with ice bags during WCS. Collected pore-waters were filtered through a $0.45 \mu \mathrm{m}$ Nylon membrane filter (with polypropylene housing), and stored frozen in acid-washed polyethylene bottles. Previous work has shown that the WCS method agrees well with other, lower-resolution, pore-water extraction techniques (i.e. centrifuging/sectioning, Rhizon-membrane sampling), for both inorganic and organic solutes in the uppermost centimeters 


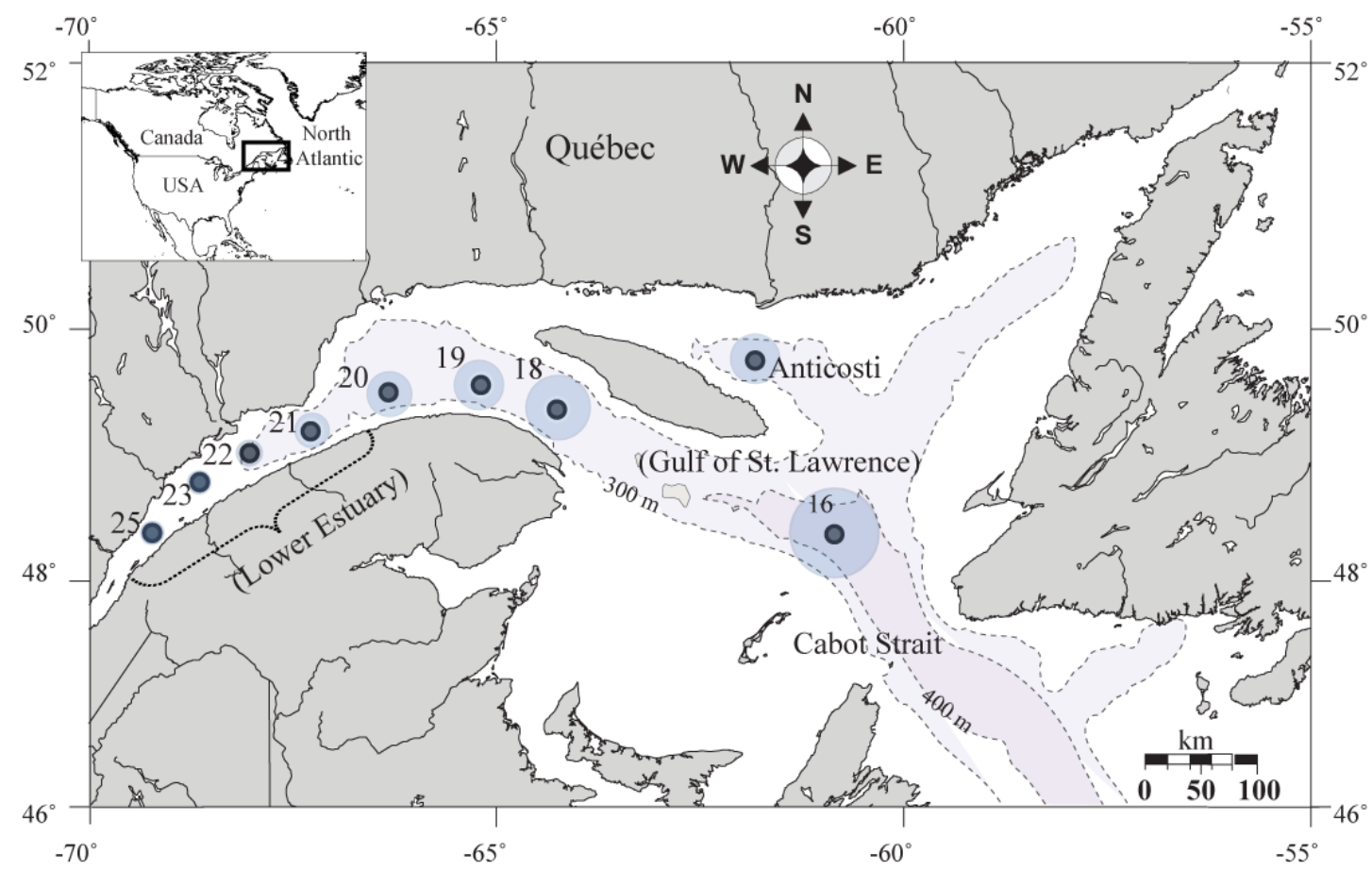

Fig. 2. Map showing the sampling locations in the St. Lawrence Estuary and the Gulf of St. Lawrence. Bathymetric contours outline the Laurentian Channel along the 300 and $400 \mathrm{~m}$ isobaths. The size of shadowed circles around study sites denotes the relative DO concentrations. For absolute values of bottom water DO see Table 1 .

(Lehmann et al., 2005; Thibodeau et al., 2010; Alkhatib et al., 2012b). Nevertheless, WCS may have effects on the concentration of solutes that are affected by adsorption or, as is probably the case with DON, which are liberated due to cell fracturing at high pressures (Bender et al., 1987). Alkhatib et al. (2012b) have shown that below two $\mathrm{cm}$ depth, WCSderived DON concentrations are artificially elevated by the squeezing process and do not represent the natural condition. However, at and just below the sediment-water interface (SWI), the agreement between the different sampling methods is excellent, so that we can assume that WCS data near the SWI provide reliable estimates on RDN concentrations and fluxes.

\subsection{Total and dissolved inorganic nitrogen concentrations}

$\mathrm{NO}_{\mathrm{x}}\left(\mathrm{NO}_{3}^{-}\right.$and $\left.\mathrm{NO}_{2}^{-}\right)$concentrations from pore water samples were determined by reduction to nitric oxide (NO) in a solution of acidic vanadium (III), followed by chemiluminescent detection of the NO using an Antek Model 7020 Nitric Oxide Analyzer (ANTEK Instruments, Houston, TX), with a precision of $\pm 0.1 \mu \mathrm{moll}^{-1}$ (Braman and Hendrix, 1989). $\left[\mathrm{NH}_{4}^{+}\right]$from pore water samples was determined using standard colorimetric autoanalyzer techniques using a Braan and Luebbe autoanalyzer, with a precision and a detection limit of $\sim 0.25 \mu \mathrm{mol} 1^{-1}$. TDN concentrations were determined by transforming all $\mathrm{N}$ containing compounds to $\mathrm{NO}_{3}^{-}$by persulfate oxidation (Knapp et al., 2005), followed by chemiluminescent detection of the $\mathrm{NO}_{3}^{-}$(Braman and Hendrix, 1989). [TDN] was corrected for any blank contribution from the persulfate oxidation reagent (on average $<3 \mu \mathrm{moll}^{-1}$ ), accounting for sample dilution. To test the oxidation efficiency of the persulfate reaction, we have measured a batch of urea and ammonia standards $\left(10 \mu \mathrm{mol}^{-1}, n=10\right)$, as well as mixed ammonia/urea standards $\left(10 \mu \mathrm{mol}^{-1}, n=10\right)$. The total yield was always in the range of 99 to $103 \%$. Ammonium and dissolved organic $\mathrm{N}$ are treated together as reduced dissolved nitrogen ([RDN]), which we calculate here as the difference between $[\mathrm{TDN}]$ and $\left[\mathrm{NO}_{\mathrm{x}}\right]$.

\subsection{Nitrogen isotope ratios}

$\mathrm{N}$ isotope measurements of nitrate were performed using the denitrifier method of Sigman et al. (2001). Briefly, 20 nmoles of sample nitrate are quantitatively converted to nitrous oxide $\left(\mathrm{N}_{2} \mathrm{O}\right)$ by denitrifying bacteria that lack active $\mathrm{N}_{2} \mathrm{O}$ reductase (Pseudomonas chlororaphis, ATCC 43928). $\mathrm{N}_{2} \mathrm{O}$ is stripped from the sample vial using helium as carrier gas, purified, and analyzed for its $\mathrm{N}$ isotopic composition with a Micromass Isoprime $^{\mathrm{TM}}$ isotope ratio mass spectrometer in continuous flow mode. Blank contribution was generally lower than $0.3 \mathrm{nmol}$ (as compared to $20 \mathrm{nmol}$ of sample N). Isotope values were calibrated using IAEA-N3 and USGS-34, 
Table 2. Sedimentary bulk particulate OM characteristics, bottom water TDN and $\mathrm{NO}_{3}^{-} \delta^{15} \mathrm{~N}$, benthic $\mathrm{N}$ isotope effects ( $\varepsilon_{\text {app }}$ and $\varepsilon_{\text {sed }}$ ), and the $\delta^{15} \mathrm{~N}$ of the benthic nitrate flux along the Laurentian Channel.

\begin{tabular}{|c|c|c|c|c|c|c|c|c|c|c|}
\hline \multirow[b]{2}{*}{ Sta. I.D. } & \multicolumn{5}{|c|}{ Sediment POM ${ }^{\mathrm{a}}$} & \multicolumn{2}{|c|}{ Bottom water } & \multirow[b]{2}{*}{$\begin{array}{l}\varepsilon_{\text {app }} \\
(\% o)\end{array}$} & \multirow[b]{2}{*}{$\begin{array}{l}\varepsilon_{\text {sed }} \\
(\% o)\end{array}$} & \multirow[b]{2}{*}{$\begin{array}{c}\delta^{15} \mathrm{~N} \text { of } \\
\mathrm{NO}_{3}^{-} \text {flux } \\
(\% \circ)\end{array}$} \\
\hline & $\delta^{15} \mathrm{~N}$ & $\% \mathrm{~N}$ & $\% \mathrm{C}_{\text {org }}$ & $\mathrm{C} / \mathrm{N}$ & $\begin{array}{l}\text { Chlorin Index } \\
\qquad(\mathrm{CI})^{\mathrm{b}}\end{array}$ & $\begin{array}{c}\delta^{15} \mathrm{~N}-\mathrm{TDN} \\
(\% \circ)\end{array}$ & $\begin{array}{c}\delta^{15} \mathrm{~N}^{-\mathrm{NO}_{3}^{-}} \\
(\% \circ)\end{array}$ & & & \\
\hline 25 & 5.52 & 0.13 & 1.31 & 11.66 & 0.63 & 6.99 & 7.25 & 2.7 & 1.5 & 4.6 \\
\hline 23 & 6.11 & 0.17 & 1.62 & 11.07 & 0.66 & 7.44 & 6.23 & 2.9 & 3.6 & 4.4 \\
\hline 22 & 6.18 & 0.15 & 1.57 & 11.95 & 0.69 & 5.92 & 5.87 & 1.2 & 3 & 4.7 \\
\hline 21 & 6.35 & 0.18 & 1.63 & 10.64 & 0.65 & 5.51 & 5.86 & 2.3 & 3.4 & 3.6 \\
\hline 20 & 7.28 & 0.18 & 1.56 & 9.84 & 0.70 & 4.89 & 6.00 & 1.2 & 5.9 & 4.8 \\
\hline 19 & 7.02 & 0.19 & 1.52 & 9.33 & 0.74 & 4.33 & 5.06 & 1.5 & 6.6 & 3.5 \\
\hline 18 & 7.08 & 0.20 & 1.59 & 9.49 & 0.77 & 4.41 & 5.09 & 1.0 & 5.8 & 4.1 \\
\hline Anticosti & 6.88 & 0.26 & 2.19 & 9.70 & 0.71 & 4.40 & 4.69 & 1.7 & 6.7 & 4.0 \\
\hline 16 & 7.01 & 0.25 & 1.85 & 8.72 & 0.82 & 4.95 & 5.23 & 1.3 & N.D. & 4.1 \\
\hline
\end{tabular}

${ }^{a}$ From Alkhatib et al. (2012a). ${ }^{b} \mathrm{CI}$ indicates OM reactivity (Schubert et al., 2005). The CI scale ranges from 0.2 for pure chlorophyll to approximately 1 for highly degraded OM. N.D. - Not determined.

international $\mathrm{KNO}_{3}$ reference materials with assigned $\delta^{15} \mathrm{~N}$ values of $+4.7 \%$ and $-1.8 \%$, respectively (Gonfiantini et al., 1995). $\mathrm{N}$ isotope ratios are reported in the conventional $\delta$-notation with respect to atmospheric dinitrogen:

$\delta^{15} \mathrm{~N}=\left[R_{\text {sample }} / R_{\text {Standard }}-1\right] \cdot 1000$

where $R$ represents the ${ }^{15} \mathrm{~N} /{ }^{14} \mathrm{~N}$ ratio. On the basis of replicate measurements of laboratory standards and samples, the analytical precision for $\delta^{15} \mathrm{~N}$ was generally $< \pm 0.2 \%$ (1 SD).

The $\delta^{15} \mathrm{~N}$ of TDN was determined by peroxidation of the TDN to $\mathrm{NO}_{3}^{-}$(see above), followed by $\mathrm{N}$ isotope analysis with the denitrifier method (Knapp et al., 2005; Bourbonnais et al., 2009). TDN- $\delta^{15} \mathrm{~N}$ was corrected for the blank contribution. IAEA-N1 $(0.4 \%$ ) and IAEA-N2 $(20.3 \%$ ) ammonium standards were oxidized and analyzed with each denitrifier run as a quality control. Replicate measurements of the standards yielded reproducible $( \pm 0.2 \%)$ and accurate results (within $0.2 \%$ for IAEA-N1 and $0.7 \%$ for IAEA-N2). A secondary "ammonium standard" correction has been applied accounting for the slight $\mathrm{N}$ isotope scale compression. The $\delta^{15} \mathrm{~N}$ of RDN was then approximated according to the equation:

$$
\begin{aligned}
\delta^{15} \mathrm{~N}_{\mathrm{RDN}}= & \left(\delta^{15} \mathrm{~N}_{\mathrm{TDN}} \cdot[\mathrm{TDN}]\right. \\
& \left.-\delta^{15} \mathrm{~N}_{\mathrm{NO}_{3}^{-}} \cdot\left[\mathrm{NO}_{3}^{-}\right]\right) /[\mathrm{RDN}] .
\end{aligned}
$$

\section{Results}

\subsection{Dissolved nitrogen concentration profiles}

Pore water nitrate and nitrite (referred to as nitrate in the discussion of this paper; nitrite in the upper portion of the profiles, near the SWI was always below detection levels) and ammonium concentration profiles in the sediments along the Laurentian Channel are presented in Fig. 3. Pore water DIN concentrations and fluxes are discussed in detail in Thibodeau et al. (2010). In brief, nitrate concentration profiles display sharp negative gradients from the SWI down to $2-3 \mathrm{~cm}$ depth at most stations, except at Sta. 16 where a subtle subsurface $\mathrm{NO}_{3}^{-}$maximum can be discerned. In some cores, nitrate concentration increased slightly at depth, but it is likely that these concentration changes were due to WCS artefacts at high pressures in the lower segments of the WCS core (Lehmann et al., 2005). The negative nitrate concentration gradients indicate that sediments were, in general, a net nitrate sink. Only at Sta. 16 did nitrate production by nitrification exceed nitrate consumption. Diffusive fluxes of nitrate calculated by Thibodeau et al. (2010) (using the same concentration profiles) were highest in the Lower Estuary (130-190 $\left.\mu \mathrm{mol} \mathrm{m}^{-2} \mathrm{~d}^{-1}\right)$, while lowest fluxes were found in the Gulf $\left(95-110 \mu \mathrm{mol} \mathrm{m}^{-2} \mathrm{~d}^{-1}\right)$. Based on Thibodeau et al. (2010) and Crowe et al. (2011), 70-90\% of the nitrate that was reduced (either by denitrification or by anammox) originated from organic $\mathrm{N}$ remineralization and nitrification. Ammonium in pore water generally displayed an increasing concentration trend with depth, yet, the concentrations remained relatively low within the first $6 \mathrm{~cm}\left(<25 \mu \mathrm{moll}^{-1}\right)$. Pore water $\left[\mathrm{NH}_{4}^{+}\right]$dropped to zero-levels in the oxic-suboxic transition zone, due to oxidation of ammonium to nitrate (nitrification). However, at some sites, incomplete nitrification within the suboxic-oxic transition zone resulted in the efflux of ammonium from sediments (e.g. Sta. 20 and 21). Clear hydrochemical evidence for anaerobic ammonium oxidation (i.e. depletion of $\mathrm{NH}_{4}^{+}$below the redox transition) was not observed, yet a recent study by Crowe et al. (2011) suggests that potential anammox can contribute as much as 

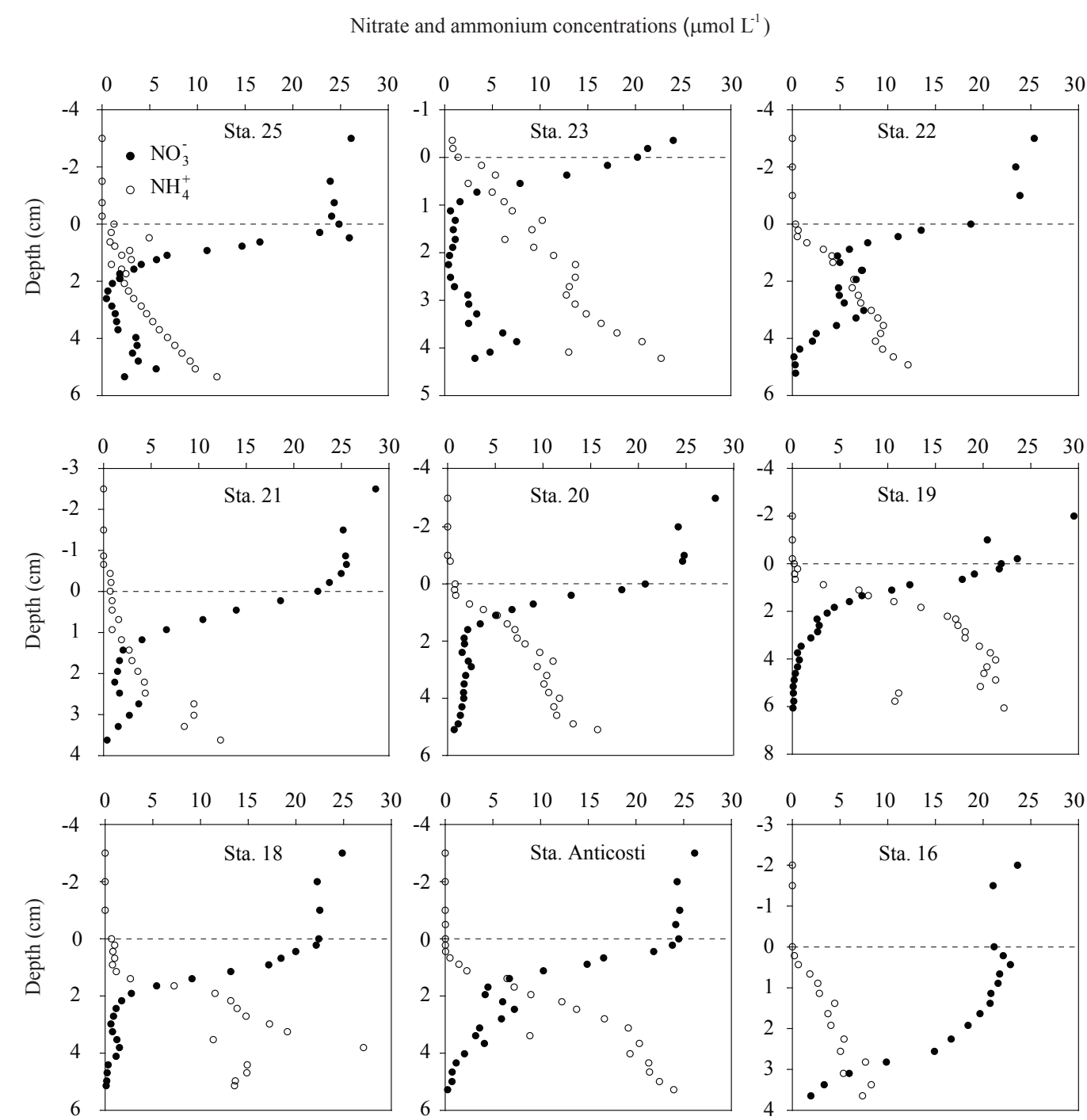

Fig. 3. Pore water nitrate and ammonium concentration profiles from locations in the St. Lawrence Estuary and the Gulf of St. Lawrence.

one third to the total DIN elimination in the Lower Estuary. TDN concentrations in the water column were $\sim 35 \mu \mathrm{moll}^{-1}$, with the dominant TDN fraction being $\mathrm{NO}_{\mathrm{x}}\left(\sim 25 \mu \mathrm{mol}{ }^{-1}\right)$. Just below the SWI, the rapid decrease in $\left[\mathrm{NO}_{3}^{-}\right]$resulted in a TDN minimum of $\sim 25 \mu \mathrm{moll}^{-1}$. With depth in the sediments, pore water [TDN] increased in a quasi-linear fashion to $80-160 \mu \mathrm{moll}^{-1}$ at $4-6 \mathrm{~cm}$ depth. Below $2-3 \mathrm{~cm}$, RDN comprises essentially all TDN. RDN, in turn, consists to the larger part of DON (Figs. 3 and 5; DON concentrations are calculated as the difference between $\mathrm{RDN}$ and $\mathrm{NH}_{4}^{+}$, not shown here; Alkhatib et al., 2012b). Comparison with pore water RDN data obtained using Rhizon membranes (Alkhatib et al., 2012b) show that, in spite of a very good agreement in the uppermost sediment column, below $2 \mathrm{~cm}$ sediment depth, WCS-derived DON concentrations were up to three-fold higher than concentrations derived using Rhizon membranes. This seems to be consistent with the liberation of
DON during cell rupture at high WCS pressures, confirming previous studies that demonstrated that WCS has a biasing effect on DOM concentrations (and likely on the $\mathrm{N}$ isotope ratios) below a certain depth (Martin and McCorkle, 1993).

\subsection{Nitrate ${ }^{15} \mathrm{~N} /{ }^{14} \mathrm{~N}$ in bottom water and pore water}

The $\delta^{15} \mathrm{~N}$ of bottom water nitrate followed a decreasing trend from the Lower Estuary to the East. The $\delta^{15} \mathrm{~N}$ was $7.2 \% \circ$ and $6.3 \%$ at the hypoxic stations 25 and 23, respectively, and decreased towards the more oxygenated locations (mean value of $5.9 \%$ at Sta. 22, 21 and 20$)$, with lowest values ( $5 \%$ o) in the Gulf (Fig. 4, Table 2). The observed trend seems to be representative not only for the near-bottom waters but for the complete water masses below the thermocline, as indicated by water column nitrate $\delta^{15} \mathrm{~N}$ profiles presented in Thibodeau et al. (2010). 


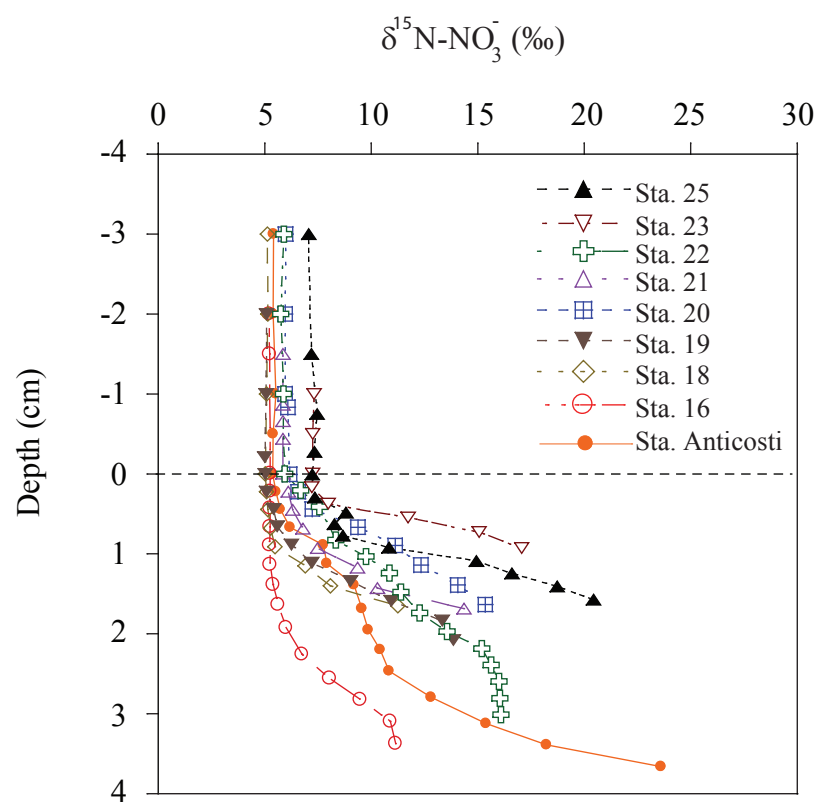

Fig. 4. Pore water nitrate $\delta^{15} \mathrm{~N}$ profiles from locations in the St. Lawrence Estuary and the Gulf of St. Lawrence.

The distribution of nitrate ${ }^{15} \mathrm{~N} /{ }^{14} \mathrm{~N}$ in pore water was similar for all stations: at some point below the SWI the $\delta^{15} \mathrm{~N}$ $\mathrm{NO}_{3}^{-}$increases as $\left[\mathrm{NO}_{3}^{-}\right]$decreases with depth (see Fig. 4), with maximum $\delta^{15} \mathrm{~N}^{-\mathrm{NO}_{3}^{-}}$of $\sim 11$ to $25 \%$ in the deeper sediments (between 2 and $3 \mathrm{~cm}$ ). Nevertheless, the $\delta^{15} \mathrm{~N}^{-\mathrm{NO}_{3}^{-}}$ gradients across the SWI varied significantly. While in the Lower Estuary (Sta. 25 to 20 ), the pore water $\delta^{15} \mathrm{~N}_{-} \mathrm{NO}_{3}^{-}$ increased right below the SWI, sediment pore water $\delta^{15} \mathrm{~N}$ $\mathrm{NO}_{3}^{-}$profiles in the Gulf (Sta. 19, 18, 16) did not show clear changes with depth in the uppermost few mm below the interface, especially not at Sta. 16 (see Fig. 4), where nitrate production is evidenced by a $\left[\mathrm{NO}_{3}^{-}\right]$maximum at $0.7 \mathrm{~cm}$.

\subsection{Sediment-water nitrate ${ }^{15} \mathrm{~N} /{ }^{14} \mathrm{~N}$ flux and the apparent $\mathrm{N}$ isotopic effect $\left(\varepsilon_{\text {app }}\right)$}

$\varepsilon_{\text {app }}$ quantifies the apparent nitrate $\mathrm{N}$ isotope effect of benthic nitrate reduction to $\mathrm{N}_{2}$, that is, the degree, to which the biological $\mathrm{N}$ isotope effects of denitrification, $\varepsilon_{\text {cell }}$, is expressed in the above-lying water column nitrate pool. $\varepsilon_{\text {app }}$ was derived from the $\left[\mathrm{NO}_{3}^{-}\right]$and $\delta^{15} \mathrm{~N}-\mathrm{NO}_{3}^{-}$pore water profiles by calculating the net ${ }^{14} \mathrm{NO}_{3}^{-}$and ${ }^{15} \mathrm{NO}_{3}^{-}$fluxes across the SWI. The latter (i.e. $F_{14} \mathrm{NO}_{3}^{-}$and $F_{15} \mathrm{NO}_{3}^{-}$, respectively) were determined from the measured concentration gradients $(\Delta C / \Delta z)$ across the SWI (i.e. the slope of the linear fits to the upper portion of profiles). Assuming the same diffusion coefficients for ${ }^{15} \mathrm{NO}_{3}^{-}$and ${ }^{14} \mathrm{NO}_{3}^{-}$, the $\delta^{15} \mathrm{~N}-\mathrm{NO}_{3}^{-}$of the nitrate flux is independent of the molecular diffusivities and can be calculated as

$\delta^{15} \mathrm{~N}_{\mathrm{Flux}_{-} \mathrm{NO}_{3}^{-}}=\left[\left(\Delta^{15} \mathrm{NO}_{3} / \Delta^{14} \mathrm{NO}_{3}\right) / R_{\mathrm{AIR}}-1\right] \cdot 1000$, where $\Delta$ refers to the concentration gradients, and $R_{\mathrm{AIR}}$ is the ${ }^{15} \mathrm{~N} /{ }^{14} \mathrm{~N}$ ratio of atmospheric nitrogen $\left(R_{\mathrm{AIR}}=0.003677\right)$. The $\delta^{15} \mathrm{~N}$ of the nitrate flux relative to the source $\delta^{15} \mathrm{~N}-\mathrm{NO}_{3}^{-}$ then corresponds to $\varepsilon_{\text {app }}$ (i.e. it is quantified as the difference between the bottom water nitrate $\delta^{15} \mathrm{~N}$ and the $\delta^{15} \mathrm{~N}$ of the benthic nitrate flux). At all stations, the nitrate removed from the bottom water was only slightly more depleted in ${ }^{15} \mathrm{~N}$ (i.e. lower $\delta^{15} \mathrm{~N}^{-\mathrm{NO}_{3}^{-}}$) than the bottom water $\mathrm{NO}_{3}^{-}$, and $\varepsilon_{\text {app }}$ ranged from 1.3 to 2.9 (Table 2). $\varepsilon_{\text {app }}$ was highest in the hypoxic portions of the Lower Estuary (Sta. 25 and 23) and at Sta. Anticosti in the Gulf, and decreased eastward along the Laurentian Channel (see Table 2).

\section{$3.4{ }^{15} \mathrm{~N} /{ }^{14} \mathrm{~N}$ of the total and reduced dissolved $\mathrm{N}$ fluxes $\left(\varepsilon_{\text {sed }}\right)$}

$\delta^{15} \mathrm{~N}$-TDN in the bottom waters was dominated by the nitrate $\delta^{15} \mathrm{~N}$, and ranged between +4 and $+7 \%$, with the higher values at the hypoxic locations $\left(\sim+7 \%\right.$ ) and more ${ }^{15} \mathrm{~N}$-depleted values in the Gulf stations ( +4.3 to $+5 \%$ o) (Fig. 5, Table 2). Below the SWI, as $\left[\mathrm{NO}_{3}^{-}\right]$decreased and $[\mathrm{RDN}]$ increased, the $\delta^{15} \mathrm{~N}$-TDN was dominated by the $\mathrm{N}$ isotopic composition of ammonium and DON (i.e. RDN). The $\delta^{15} \mathrm{~N}-\mathrm{RDN}$ ranged between $2 \% o$ and $6 \%$ in the bottom waters and generally increased with depth and concentration to values between 5 and $10 \% o$ at $2 \mathrm{~cm}$ depth (Fig. 5). At Sta. 25 and to a lesser extent at Sta. 23, Sta. 22, and Sta. 21, the change in $\delta^{15} \mathrm{~N}-\mathrm{RDN}$ with depth was relatively minor. The difference between the $\delta{ }^{15} \mathrm{~N}$-TDN in the bottom water column and that in the pore water (which is the master factor in determining the overall $\mathrm{N}$ isotope effect during the exchange of the different $\mathrm{N}$ species across the SWI) seems to increase eastwards along the Laurentian Channel. Using the RDN isotope data in the upper $2 \mathrm{~cm}$ of the sediments (i.e. down to a depth which is not affected by WCS artefacts), analogous to the use of nitrate $\mathrm{N}$ isotope data above to calculate $\varepsilon_{\text {app }}$, we calculated the RDN N isotope flux across the SWI. However, RDN profiles were clearly not linear in the vicinity of the SWI, and the first derivative at $z=0$ of the exponential fits was used to calculate nitrate isotope concentration gradients. The RDN N isotope flux was then combined with the nitrate $\mathrm{N}$ isotope flux from above to yield estimates of $\varepsilon_{\text {sed }}$, the overall $\mathrm{N}$ isotope effect of benthic DIN removal. We found that the $\varepsilon_{\text {sed }}$ values were in the same range, or slightly higher than, the $\varepsilon_{\text {app }}$ values for all the St. Lawrence Estuary and Gulf stations, yet all of them were $<7 \%$ (see Table 2 ).

\section{Discussion}

\subsection{Distribution of the nitrate and TDN ${ }^{15} \mathrm{~N}$ in sediment pore waters}

The inverse correlation between nitrate $\delta^{15} \mathrm{~N}$ and $\left[\mathrm{NO}_{3}^{-}\right]$suggests that nitrate consumption within the sediments occurs with a significant intrinsic (or biologic) $\mathrm{N}$ isotope effect, 
$[\mathrm{TDN}]\left(\mu \mathrm{mol} \mathrm{L}^{-1}\right)$

$\delta^{15} \mathrm{~N}-\mathrm{TDN}(\%)$
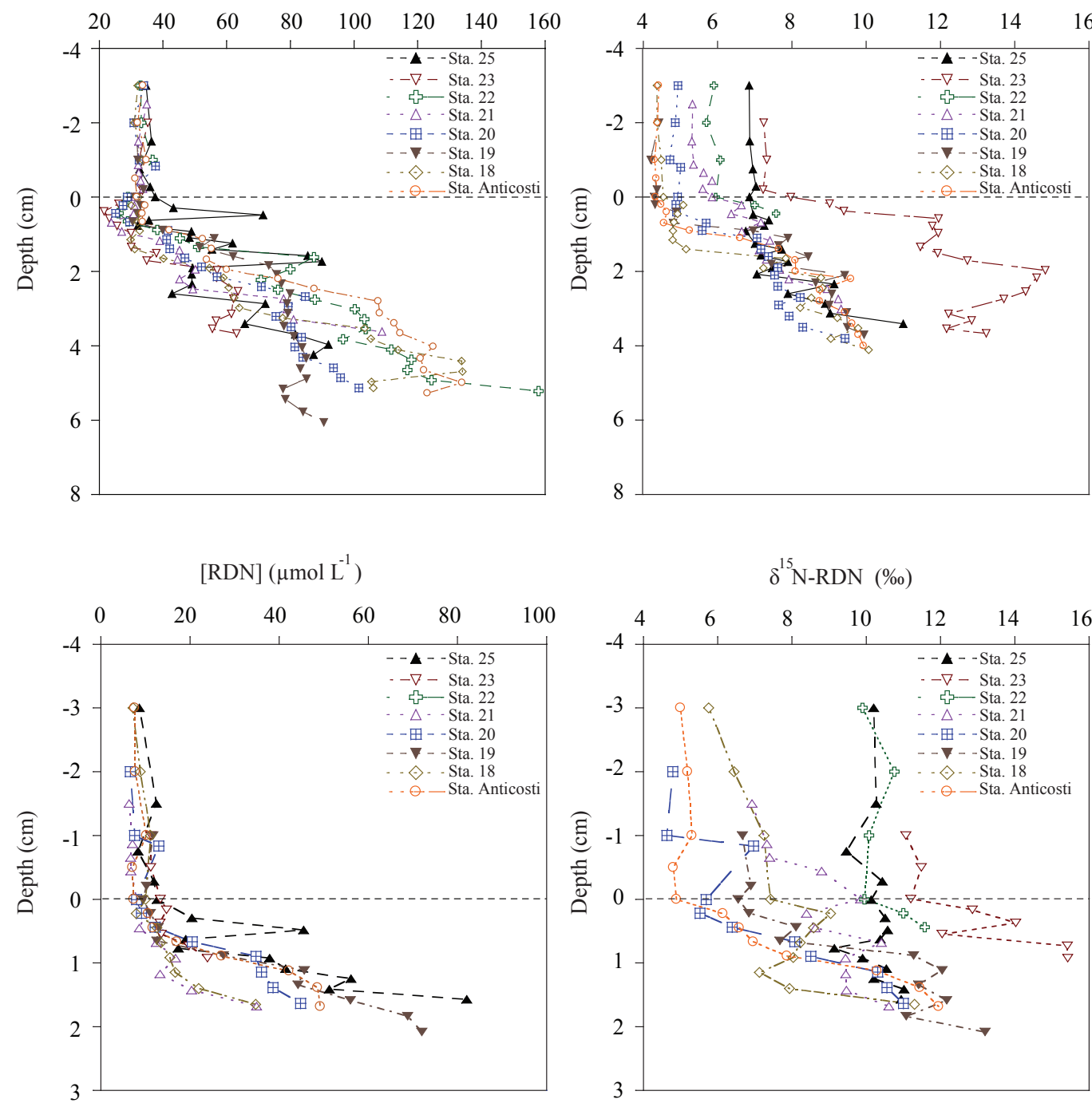

Fig. 5. Depth distribution of total dissolved nitrogen (TDN) (upper panels) and reduced dissolved nitrogen (RDN) (lower panels), and $\delta^{15} \mathrm{~N}$ of TDN and RDN in pore water from sediments in the St. Lawrence Estuary and the Gulf of St. Lawrence.

which results from the discrimination against ${ }^{15} \mathrm{~N}$ by nitratereducing bacteria. Although not completely adequate to describe nitrate $\mathrm{N}$ isotope fractionation within sediment pore waters (Lehmann et al., 2007), the biological $\mathrm{N}$ isotope effect $\varepsilon_{\text {cell }}$ of net nitrate consumption can be approximated assuming Rayleigh model dynamics: the slope of the linear regression between $\delta^{15} \mathrm{~N}_{-} \mathrm{NO}_{3}^{-}$vs. $\ln \left[\mathrm{NO}_{3}^{-}\right]$, yields estimates of the biological $\mathrm{N}$-isotope fractionation during nitrate consumption in the sediments $\left(\varepsilon_{\text {cell_Rayleigh }}\right)$ (Mariotti et

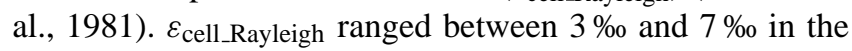
St. Lawrence estuarine and Gulf sediments (Fig. 6), within the lower range of the values reported for deep-sea sediments in the Bering Sea (between 4\%o and 17\%o). N elimination in St. Lawrence Estuary sediments is dominated by nitrification-denitrification coupling (Thibodeau et al., 2010; Crowe et al., 2011), and diffusive supply of water-column nitrate for denitrification plays a lesser role. While sediments in general violate one of the basic assumptions of a closedsystem model, leading to underexpression of the biological $\mathrm{N}$ isotope effect when calculating $\varepsilon_{\text {cell_Rayleigh (Lehmann et }}$ al., 2007), the production of ${ }^{15} \mathrm{~N}$-depleted nitrate from nitrification may be particularly efficient in dampening the actual nitrate ${ }^{15} \mathrm{~N}$ enrichment with respect to a given nitrate deficit. Furthermore, physiological effects may play a certain role in keeping $\varepsilon_{\text {cell }}$ at low levels (e.g. low substrate availability at the active denitrification site; Lehmann et al., 2007).

At most stations, we observed a decrease of the $\delta^{15} \mathrm{~N}-\mathrm{RDN}$ from $\sim 2 \mathrm{~cm}$ sediment depth towards the SWI (see Fig. $5 \mathrm{~d}$ ). 


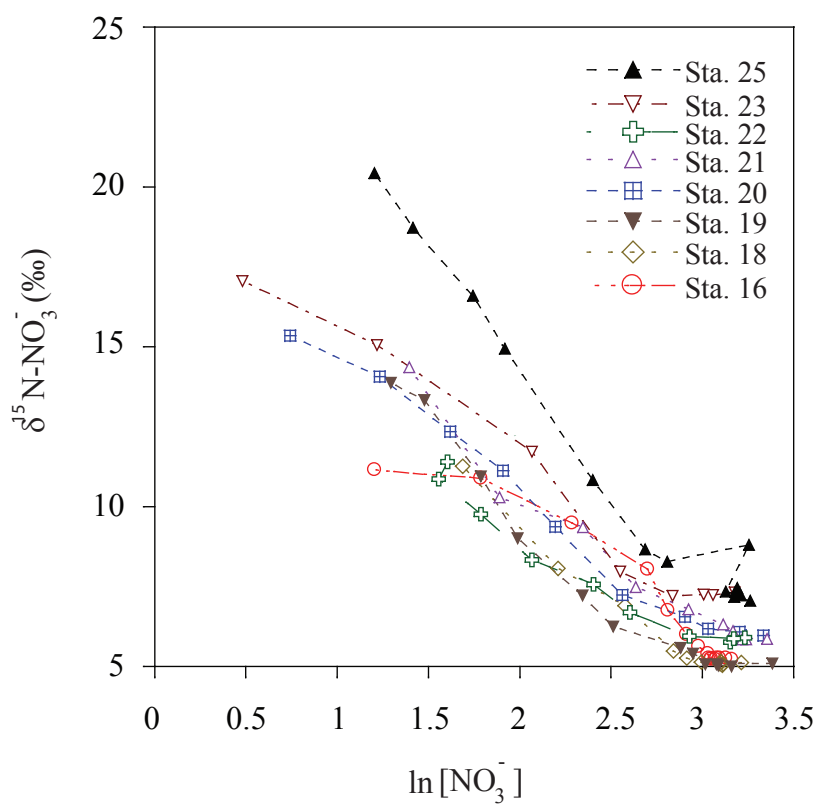

Fig. 6. Change of the nitrate $\delta^{15} \mathrm{~N}$ as function of the natural logarithm of the pore water nitrate concentration. The slopes of the linear regression lines correspond to the nitrate $\mathrm{N}$ isotope effects of net nitrate consumption within the sediments $\left(\varepsilon_{\text {Rayleigh }}\right)$. For the St. Lawrence sediments $\varepsilon_{\text {Rayleigh }}$ ranged between $+3 \%$ and $+7 \%$.

In accordance with observations by Prokopenko et al. (2006) in marine sediments of the Eastern Subtropical North Pacific and the Santa Barbara Basin, the $\delta^{15} \mathrm{~N}-\mathrm{RDN}$ at the deeper end of this depth segment matches the $\delta^{15} \mathrm{~N}$ of sediment POM $( \pm 0.5 \%$ ) (except at Sta. 23 where the average pore water $\delta^{15} \mathrm{~N}-\mathrm{RDN}$ was significantly higher than $\delta^{15} \mathrm{~N}-\mathrm{POM}$ ), suggesting the liberation of $\mathrm{N}$ during POM remineralization without significant $\mathrm{N}$ isotope fractionation. The cause for the ${ }^{15} \mathrm{~N}$ depletion of RDN in the subsurface pore water (and ultimately in the RDN pool in the water column) is unclear. The observed decrease in $\delta^{15} \mathrm{~N}$-RDN implies a source of low- $\delta{ }^{15} \mathrm{~N}$ DON just below the SWI. A low- $\delta^{15} \mathrm{~N}$ ammonium source is unlikely, as almost complete consumption of ammonium would produce RDN ${ }^{15} \mathrm{~N}$-enrichment rather than ${ }^{15} \mathrm{~N}$-depletion. Urea can be a major nitrogen excretion product from bacteria in marine sediments (Lomstein et al., 1989; Pedersen et al., 1993; Sloth et al., 1995), which could, if depleted in ${ }^{15} \mathrm{~N}$, contribute to the observed $\delta^{15} \mathrm{~N}$ decrease in the pore water RDN just below the SWI where bacterial respiration rates are high. Alternatively, bacterial uptake of DON could have caused the observed decrease in $\delta^{15} \mathrm{~N}-\mathrm{RDN}$, if preferential incorporation of high $\delta^{15} \mathrm{~N}-\mathrm{DON}$ into bacterial biomass occurs. Given the work of Macko and Estep (1984), the partitioning of DON during bacterial DON assimilation into a "lighter" ammonium and a "heavier" PON pool is indeed plausible. While we can only speculate about the exact controls on the pore water $\delta^{15} \mathrm{~N}-\mathrm{RDN}$ trend, it is evident that the bulk pore water RDN pool in the upper two $\mathrm{cm}$ of the sediment column has still a slightly higher $\delta^{15} \mathrm{~N}$ than the RDN in the water column, implying that the sediments are a source of ${ }^{15} \mathrm{~N}$-enriched RDN.

\subsection{Controls on the nitrate $N$ isotope $\varepsilon_{\text {app }}$ effect during nitrate removal}

As discussed in the previous section, net denitrification in the St. Lawrence estuarine sediments was associated with a substantial biological $\mathrm{N}$ isotopic fractionation at the cell-level, leaving the residual pore water nitrate pool enriched in ${ }^{15} \mathrm{~N}$. A significant water column nitrate deficit $\left(\mathrm{N}^{*} \sim-10 \mu \mathrm{mol}^{-1}\right)$ has been identified by Thibodeau et al. (2010) in the hypoxic bottom water column in the Lower Estuary, yet this nitrate deficit, which can exclusively be attributed to benthic denitrification (see Table 1 for rates), is not associated with any significant nitrate $\mathrm{N}$ isotope effect in the water column. Hence, as has been described for other marine environments (Brandes and Devol, 1997; Lehmann et al., 2004, 2007), the biological $\mathrm{N}$ isotope fractionation, as evidenced by strong nitrate $\delta^{15} \mathrm{~N}$ gradients within the sediment pore water, appears to be suppressed at the scale of sediment water nitrate exchange also in the estuarine sediments of the Laurentian Channel. In agreement with reports from other marine benthic environments (Brandes and Devol, 1997; Sigman et al., 2003; Lehmann et al., 2004), the calculated $\varepsilon_{\text {app }}$ values between 1 and $3 \%$ confirmed a large degree of under-expression of the biological $\mathrm{N}$ isotope fractionation during nitrate consumption from the bottom waters. Despite extensive $\mathrm{NO}_{3}^{-}$removal within the sediment pore water pool (Thibodeau et al., 2010; Table 1), and in spite of the strong nitrate ${ }^{15} \mathrm{~N}$ enrichment associated with the nitrate removal, the $\delta^{15} \mathrm{~N}-\mathrm{NO}_{3}^{-}$in the bottom water barely increased. Based on previous work by Brandes and Devol (1997) and Lehmann et al. $(2004,2007)$, we attribute the apparent suppression of the biological $\mathrm{N}$ isotope effect to the limited diffusive $\mathrm{NO}_{3}^{-}$ supply to the site of denitrification in the sediment, and/or the gross production of ${ }^{15} \mathrm{~N}$ depleted nitrate through incomplete nitrification of pore water ammonium.

Although the spatial changes in $\varepsilon_{\text {app }}$ are subtle, it appears that higher $\varepsilon_{\text {app }}$ values were generally found in the Lower Estuary at stations that exhibit the highest sedimentary OM reactivity and that are overlain by the least oxygenated (hypoxic) bottom water along the Laurentian Channel (see Table 2; Alkhatib et al., 2012a). Relatively low $\varepsilon_{\text {app }}$ values were determined for the Gulf sediments (e.g. Sta. 16), which are characterized by the lowest OM reactivity and high bottom water $\left[\mathrm{O}_{2}\right]$. The general under-expression of $\varepsilon_{\text {cell }}$ along the Laurentian Channel $\left(\varepsilon_{\text {app }} \leq 3 \%\right.$ o $)$ appears to be related to the supply and consumption of nitrate within the denitrification zone under diffusion limitation. In particular, the reactivity of the OM and the bottom water oxygenation may both affect the oxygen penetration depth (OPD) and, hence, the nitrate gradient across the SWI, as well as the corresponding diffusive nitrate flux. 
We found a good correlation between $\varepsilon_{\text {app }}$ and OPD $\left(r^{2}=0.66, n=6\right.$; Fig. 7a), and a significant inverse correlation between the overlying bottom water $\delta^{15} \mathrm{~N}^{-\mathrm{NO}_{3}^{-}}$and OPD $\left(r^{2}=0.82, n=6\right.$; Tables 1 and 2). Hence our observational data seem to confirm previous model-based results by Lehmann et al. (2007), which indicate close links between $\varepsilon_{\text {app }}$, OPD, and the depth of denitrification. There is also a significant correlation between $\mathrm{OM}$ reactivity (quantified as Chlorin Index; data from Alkhatib et al., 2012a) and $\varepsilon_{\text {app }}$ along the Laurentian Channel $\left(r^{2}=0.52, n=9\right.$; Fig. 7b), which further suggests that $\mathrm{OM}$ reactivity has a significant influence on $\varepsilon_{\text {app }}$ at low levels by modulating OPD, ammonium production, and thus nitrate availability. As the denitrification zone is forced deeper into sediments, the diffusive transport of nitrate to the denitrification zone is decreased, and it is less likely that $\varepsilon_{\text {cell }}$ is expressed in the water column. As the denitrification zone shifts closer to the sediment surface, due to a lowered OPD (e.g. in a more reactive benthic environment), denitrifiers will consume nitrate from a larger nitrate pool, enhancing the expression of $\varepsilon_{\text {cell }}$ at the scale of sedimentwater solute exchange (Lehmann et al., 2007). OPD, and hence the depth of the denitrification zone, seems to be the main constraint on $\varepsilon_{\text {app }}$, through its direct control on the nitrate pool size at the depth where denitrification occurs. At the same time, in particular in low-reactivity environments, it is also possible that nitrification rates can exceed net denitrification (Berelson et al., 1990). For example, at Sta. 16 the sediments represent a source of nitrate (Table 1). Partial nitrification of upward diffusing and regenerated ammonium produces ${ }^{15} \mathrm{~N}$-depleted nitrate (e.g. Sigman et al., 2001; Wankel et al., 2009), which can compensate any nitrate ${ }^{15} \mathrm{~N}$ enrichment to the point that the nitrate $\delta^{15} \mathrm{~N}$ gradient across the SWI is significantly lowered or even reversed.

\subsection{The total sedimentary $N$ isotopic effect $\varepsilon_{\text {sed }}$}

As mentioned in the last section, nitrate produced from incomplete remineralization/nitrification can partially offset the ${ }^{15} \mathrm{~N}$ enrichment by denitrification. Another more direct effect of remineralization on the $\mathrm{N}$ isotope composition of the water column TDN can result from the actual $\mathrm{NH}_{4}^{+}$and DON efflux from the sediments into the bottom water. For example, as low $\delta^{15} \mathrm{~N}^{-\mathrm{NO}_{3}^{-}}$is produced from partial nitrification, ${ }^{15} \mathrm{~N}$-enriched ammonium is left behind and may escape to the water column, increasing the overall $\mathrm{N}$ isotope effect of benthic $\mathrm{N}$ cycling (Lehmann et al., 2007). As a consequence, while the $\mathrm{N}$-isotopic fractionation during nitrification may reduce $\varepsilon_{\text {app }}$ it can increase $\varepsilon_{\text {sed }}$, and we suggest this is the case at least at some of our sites. At stations where $\left[\mathrm{NH}_{4}^{+}\right]$was not zero at the SWI, and $\mathrm{NH}_{4}^{+}$ fluxes out of the sediments, $\mathrm{N}$ isotope signatures that result from partial nitrification are propagated into the water column. In the same vein, under suboxic conditions, nitrate can be converted into ammonium via DNRA. Although the isotopic effect of DNRA has not yet been investigated, it is likely that partial ammonification of nitrate most probably produces ${ }^{15} \mathrm{~N}$ depleted ammonium (Lehmann et al., 2007). Through ${ }^{15} \mathrm{NO}_{3}^{-}$label ex-situ core incubations, Thibodeau et al. (2010) demonstrated that DNRA contributes to total nitrate reduction at Sta. 18. However, the relatively high $\delta^{15} \mathrm{~N}$ values for porewater RDN at essentially all stations argue against an important effect of DNRA on the reduced nitrogen pool, in agreement with Crowe et al. (2011), who found that the rate of DNRA is three orders of magnitude lower than denitrification and anammox and is therefore insignificant to $\mathrm{N}$-cycling in the St. Lawrence Estuary.

Calculated $\varepsilon_{\text {sed }}$ values from sediments along the Laurentian Channel varied between $1.5 \%$ and $6.7 \%$, and $\varepsilon_{\text {sed }}$ seemed to increase eastward along the Laurentian Channel (i.e. lower $\varepsilon_{\text {sed }}$ values were observed for the Lower Estuary, while rather high values were found in the Gulf; see Table 2). The $\varepsilon_{\text {sed }}$ values are, on average, higher than the $\varepsilon_{\text {app }}$ values. The elevation of $\varepsilon_{\text {sed }}$ over $\varepsilon_{\text {app }}$ at most Laurentian Channel stations (particularly to the east) can be explained by the efflux of RDN into the water column, which has, at most stations, a higher $\delta^{15} \mathrm{~N}$ than the water column RDN pool. One would expect that OM remineralization (and associated $\mathrm{N}$-isotope fractionation) and the $\delta^{15} \mathrm{~N}$ of the source $\mathrm{OM}$, as well as the degree to which nitrification of mineralized $\mathrm{NH}_{4}^{+}$ by bacteria is complete is a major determinant of $\varepsilon_{\text {sed }}$. Indeed, $\varepsilon_{\text {sed }}$ correlates significantly with both CI $\left(r^{2}=0.65\right.$, $n=8$; Fig. 7d) and DO in the bottom water $\left(r^{2}=0.76, n=8\right.$; Tables 1 and 2). $\varepsilon_{\text {sed }}$ also correlates with the oxygen penetration depth in sediments $\left(r^{2}=0.76, n=6\right.$; Fig. 7c), as well as with the oxygen exposure time $\left(r^{2}=0.57, n=5\right.$; Tables 1 and 2), suggesting that, as with $\varepsilon_{\mathrm{app}}$, OM reactivity and oxygen concentration play a significant role in controlling the combined isotope effects of benthic $\mathrm{N}$-cycle processes on the water column TDN pool. As mentioned earlier, the efflux of high $\delta^{15} \mathrm{~N}-\mathrm{NH}_{4}^{+}$can by itself raise $\varepsilon_{\text {sed }}$ values. However, it is important to note that, as the $\mathrm{NH}_{4}^{+}{ }^{15} \mathrm{~N}$-enrichment in the pore water $\mathrm{NH}_{4}^{+}$pool must be paralleled by the production of low- $\delta^{15} \mathrm{~N}$ nitrate, isotope fractionation during nitrification only increases $\varepsilon_{\text {sed }}$ if new, low $\delta^{15} \mathrm{~N}^{-\mathrm{NO}_{3}^{-}}$is directly denitrified (coupled nitrification-denitrification), and the $\mathrm{NH}_{4}^{+}$ is not completely oxidized within the sediments. Granger et al. (2011) found a significant direct relationship between the efflux of ammonium from Bering Sea Shelf sediments and the water column $\delta^{15} \mathrm{~N}-\mathrm{NO}_{3}^{-}$. Similarly, Brandes and Devol (1997) found that the $\delta^{15} \mathrm{~N}_{-} \mathrm{NH}_{4}^{+}$that diffused out of the sediments of Puget Sound was on average $4.5 \%$ o heavier than both that of source organic matter within the sediments and the overlying water $\mathrm{NO}_{3}^{-}$. It could be hypothesized that $\varepsilon_{\text {sed }}$ is a function of the ammonium efflux ratio (i.e. the ratio between $\mathrm{NH}_{4}^{+}$remineralization and $\mathrm{NH}_{4}^{+}$efflux; Lehmann et al., 2004) in the Laurentian Channel, as was proposed for the Bering Sea shelf (Granger et al., 2011). However, at most of our sites, $\mathrm{NH}_{4}^{+}$appeared to be quantitatively oxidized within the sediments, and where $\mathrm{NH}_{4}^{+}$flux was observed, $\varepsilon_{\text {sed }}$ was 

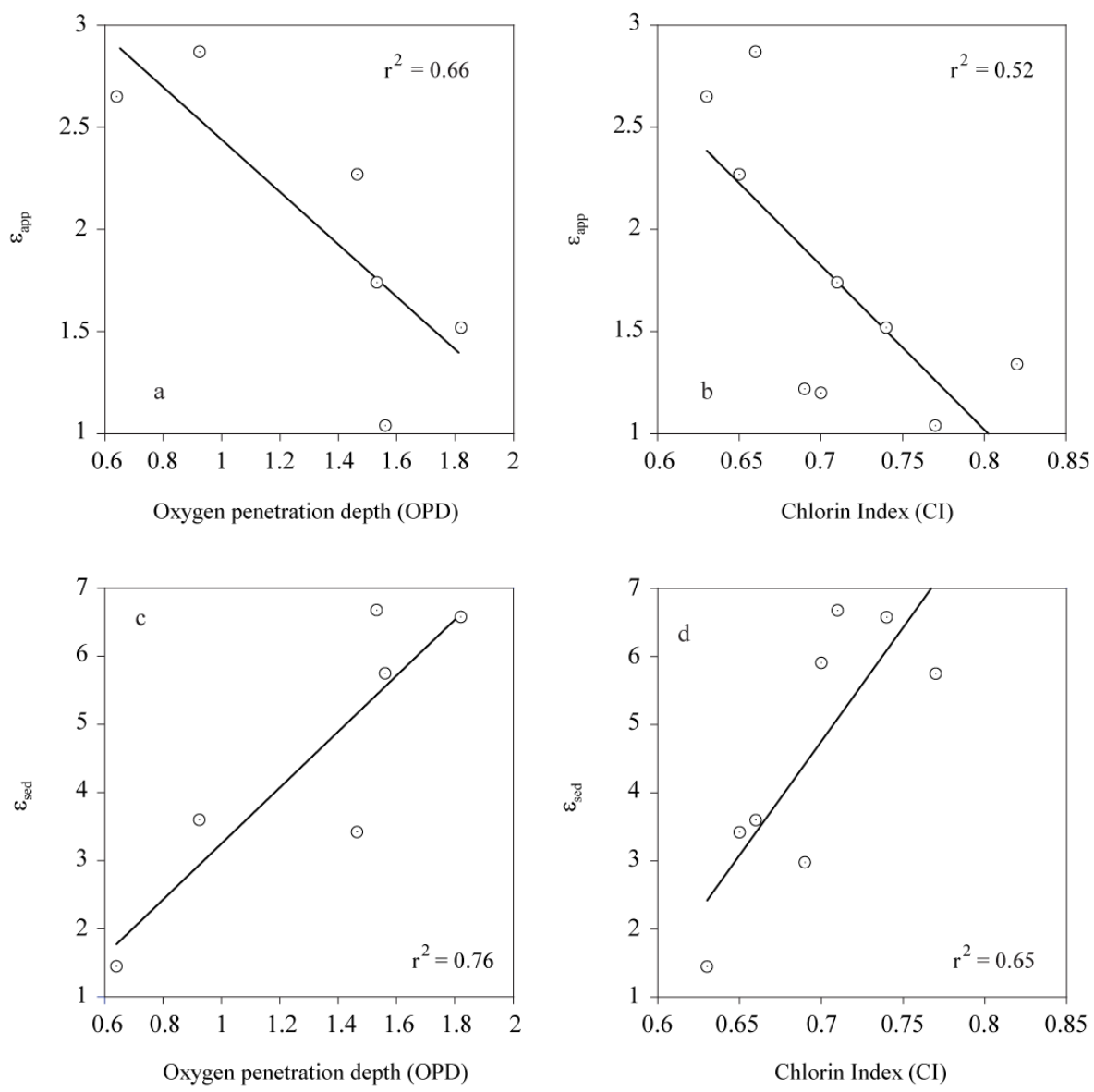

Fig. 7. Correlation between $\varepsilon_{\text {app }}$ and (a) the oxygen penetration depth (OPD), and (b) the Chlorin Index (CI), as well as between $\varepsilon_{\text {sed }}$ and (c) OPD and (d) CI. CI indicates OM reactivity (Schubert et al., 2005). The CI scale ranges from 0.2 for pure chlorophyll to approximately 1 for highly degraded OM.

not particularly high (e.g. Sta. 21). Hence, we argue that it is the amount and $\mathrm{N}$ isotopic composition of the effluxing DON that represent the most important constraints on $\varepsilon_{\text {sed. }}$. Interestingly, $\varepsilon_{\text {sed }}$ was highest where surface sediment $\mathrm{OM}$ $\delta^{15} \mathrm{~N}$ values were also highest (see Table 2).

Finally, bioturbation/bioirrigation is yet another aspect that may have contributed to the observed trends in $\varepsilon_{\text {sed }}$ (and $\varepsilon_{\text {app }}$ ) along the Lower Estuary and the Gulf. Belley et al. (2010) found that the macrobenthos surface-trace density was highest at the head of the channel (Sta. 25 and Sta. 23) and that it decreased noticeably eastward along the LC. This observation was explained by the fact that the hypoxic area of the LC is now in a transition phase, where suspension feeders, non-tolerant to hypoxia, are progressively replaced by low-oxygen tolerant deposit feeders that are mainly responsible for surficial benthos traces (e.g. Ophiura sp.). The possible effect of bioturbation/bioirrigation on $\varepsilon_{\text {sed }}$ remains uncertain. Bioirrigation in general facilitates the DIN and RDN exchange between the bottom and porewaters, and thus may allow "deeper" RDN with higher $\delta^{15} \mathrm{~N}$ to escape the sediments, by-passing the diagenetically active reaction zone right below the SWI, and increasing the $\varepsilon_{\text {sed. }}$. At the same time, oxygen is supplied to anoxic regions within the sediments, pushing down the active denitrification zone, and reducing the porewater nitrate concentration gradient. This deepening of the oxic layer can, on the one hand, enhance nitrate diffusion limitation and thus reduce $\varepsilon_{\text {sed }}$ (see above), it may also stimulate nitrification at greater sediment depths and may thus act to remedy nitrate diffusion limitation on the other hand. Lehmann et al. (2004) have argued that even in strongly bioirrigated environments the $\mathrm{N}$ isotope effect of benthic microbial denitrification is essentially not expressed. Our study attests to this notion, as none of the observed $\varepsilon_{\text {app }}$ is greater than $3 \%$, and lowest $\varepsilon_{\text {sed }}$ co-occur with the highest density of surface traces.

\subsection{Implications for the marine $\mathrm{N}$-isotope budget}

$\varepsilon_{\text {sed }}$ approximates the difference between the $\delta^{15} \mathrm{~N}$ of all reactive $\mathrm{N}$ in the water column and the $\delta^{15} \mathrm{~N}$ of $\mathrm{N}$ lost by suboxic $\mathrm{N}_{2}$ production, and thus, understanding $\varepsilon_{\text {sed }}$, more than $\varepsilon_{\mathrm{app}}$, is critical for $\mathrm{N}$ isotope budgets (Lehmann et al., 
2007; Granger et al., 2011). Lehmann et al. (2007) have simulated environmental scenarios where $\varepsilon_{\text {sed }}$ can be up to $5 \%$ (when coupled nitrification-denitrification is associated with a flux of $\mathrm{NH}_{4}^{+}$out of the sediments). While they did not include DON in their $\mathrm{N}$ isotope flux calculations, their scenario of intermediate $\mathrm{OM}$ reactivity and intermediate oxygenation of bottom water reflects well the environmental conditions along the Laurentian Channel, and the agreement between modelled and observed values of $\varepsilon_{\text {sed }}$ and $\varepsilon_{\text {app }}$ is remarkably good (see Tables 1 and 2). Moreover, using a different approach, Granger et al. (2011) estimated that the N isotope effects of sedimentary nitrification-denitrification coupling on the Bering Sea Shelf water column (derived from the $\delta^{15} \mathrm{~N}$ of surface sediments with respect to the reactive $\mathrm{N}$ deficit in the water column) ranged between $6 \%$ and $8 \%$. The weak coupling between nitrification and denitrification in the Bering Sea shelf allowed for large amounts of ammonium- $\mathrm{N}$ to escape consumption inside the sediments, which resulted in such high $\varepsilon_{\text {sed }}$ values. From the global $\mathrm{N}$-isotope balance perspective, the degree to which $\mathrm{N}$ isotope fractionation due to benthic $\mathrm{N}$ elimination, the main $\mathrm{N}$ sink in the oceanic $\mathrm{N}$ cycle, finds its expression in the water column is of fundamental importance. Our data reveal that the biological $\mathrm{N}$ isotope effect of estuarine benthic $\mathrm{N}$ elimination is highly suppressed, confirming observations from other benthic environments (Brandes and Devol, 2007; Lehmann et al., 2004, 2007; Granger et al., 2011). However, both $\varepsilon_{\text {sed }}$ and $\varepsilon_{\text {app }}$ can be significantly different from zero, and can vary as a function of the sediment reactivity and bottom water oxygenation. The conditions along the Laurentian Channel, especially in the Gulf of St. Lawrence can be considered representative of coastal and continental shelf environments where most of the global sedimentary denitrification occurs. Given the mean ocean DIN $\delta^{15} \mathrm{~N}$ of approximately $5.5 \%$ and an input of $\mathrm{N}$ through $\mathrm{N}_{2}$ fixation with a $\delta^{15} \mathrm{~N}$ of $-2-0 \%$, a globally applicable $\varepsilon_{\text {sed }}$ value of $5 \%$ (as calculated using our field data) or even higher (Granger et al., 2011) would indicate that essentially all denitrification occurs within the benthic environment, leaving little space for water column denitrification with a significantly higher $\mathrm{N}$ isotope effect (according to the approach by Brandes and Devol, 2002). Such a large attribution of benthic denitrification to the global $\mathrm{N}$ loss is not considered in current observations (Brandes and Devol, 1997; Fennel et al., 2006), and would imply that global N loss by far exceeds global $\mathrm{N}$ inputs, yielding a completely imbalanced $\mathrm{N}$ budget. While our observational data now confirm that $\varepsilon_{\text {sed }}$ values of $5 \%$ and greater are possible, benthic denitrification must occur to large parts with a lower $\varepsilon_{\text {sed }}$, for example in deep sea sediments, where the average $\varepsilon_{\text {sed }}$ is assumed to be $\sim 2 \%$ o (Lehmann et al., 2007).

\section{Conclusions}

Independent of the sedimentary OM reactivity and bottom water $\left[\mathrm{O}_{2}\right]$ regimes, the biological nitrate $\mathrm{N}$ isotope effect is significantly under-expressed at the scale of sediment-water nitrate exchange. This observation, for the first time made in an estuary, is in agreement with findings from other marine environments (Brandes and Devol, 1997; Lehmann et al., 2004, 2007), underscoring that a low $\varepsilon_{\text {app }}$ applies to a wide spectrum of environmental conditions. We conclude that sediment $\mathrm{OM}$ reactivity and [DO] in bottom water interact to yield a low nitrate supply to the denitrification zone inside the sediment, so that diffusion limitation will keep the $\varepsilon_{\text {app }}<3 \%$ o. Nevertheless, subtle but consistent changes in $\varepsilon_{\text {app }}$ were discerned along the Laurentian Channel, with putative links to bottom water oxygenation and sediment $\mathrm{OM}$ reactivity. Hence, our observational data are consistent with recent model results that point to $\mathrm{OM}$ reactivity and the $\mathrm{O}_{2}$ penetration depth as important controls of the $\mathrm{N}$ isotope effect during nitrate exchange between the sediments and the overlying water column (Lehmann et al., 2007).

We have analyzed the patterns in $\varepsilon_{\text {sed }}$ for the first time in the context of $\mathrm{N}$ isotopic measurements of reduced dissolved $\mathrm{N}$ species $\left(\mathrm{DON}+\mathrm{NH}_{4}^{+}\right)$. The values of $\varepsilon_{\text {sed }}$ approximate the difference between the $\delta^{15} \mathrm{~N}$ of reactive $\mathrm{N}$ in the water column that is ultimately lost in sediments through suboxic $\mathrm{N}_{2}$ production and the $\delta^{15} \mathrm{~N}$ of the lost $\mathrm{N}_{2}$. Thereby, they consider the coupling between remineralization, nitrification, and denitrification (and other $\mathrm{N}$ transformations not explicitly addressed here; e.g. anammox). Previous work has not included the DON flux from the benthic environment in $\varepsilon_{\text {sed }}$ calculations, on the basis that DON remineralization does not add substantially to the reactive water column $\mathrm{N}$ pool. While we agree that the mean oceanic $\mathrm{N}$ pool consists of DON that is of rather refractory nature (Knapp et al., 2005; Bourbonnais et al., 2009), we argue that the inert character of the water column DON pool does not preclude that a dominant fraction of DON that fluxes out of marine sediments undergoes rapid oxidation and adds to the oceanic DIN pool. Otherwise, it would be difficult to explain the discrepancy between the relatively large estuarine and coastal benthic DON fluxes (Alkhatib et al., 2012b) and the low DON concentrations in the ocean water column (e.g. Knapp et al., 2005; Bourbonnais et al., 2009). As a consequence, we emphasize here that DON fluxes need to be included in $\varepsilon_{\text {sed }}$ calculations and conclude that $\mathrm{OM}$ remineralization can modulate the overall $\mathrm{N}$ isotope effect of benthic $\mathrm{N}$ elimination. As we did not distinguish between $\mathrm{NH}_{4}^{+}$and DON, we can only speculate on the reason for a generally low $\delta^{15} \mathrm{~N}$ of the RDN in both the water column and the sediment pore waters, as well as processes that determine the RDN efflux. Future work should directly address the $\mathrm{N}$ isotopic impact of sediment/water ammonium versus DON fluxes. Our data clearly show that the flux of RDN out of the sediments is consistently enriched in 
${ }^{15} \mathrm{~N}$ with respect to the water column RDN pool, most often elevating $\varepsilon_{\text {sed }}$ over $\varepsilon_{\text {app }}$. In agreement with previous model simulations (Lehmann et al., 2007), our observational data indicate that the degree of under-expression of the biological $\mathrm{N}$ isotope effect of sedimentary $\mathrm{N}$-elimination seems to be a function of the environmental conditions (bottom water oxygenation and oxygen penetration depth in particular), and also of the reactivity and $\delta^{15} \mathrm{~N}$ of the sedimenting OM. These parameters all modulate the amount and the $\delta^{15} \mathrm{~N}$ of the regenerated $\mathrm{N}$ that is ultimately denitrified. The variability in $\varepsilon_{\text {sed }}$ within a range of $4.6 \pm 2.5 \%$ observed for the St. Lawrence system is consistent with previous projections of a mean global $\varepsilon_{\text {sed }}$ value on the order of $4 \%$ o (Lehmann et al., 2007). Nevertheless, these values of $\varepsilon_{\text {sed }}$ are larger than previously assumed, and result in inconsistencies with current $\mathrm{N}$ isotope budgets, because they imply a greater sediment-to-water column denitrification ratio and, thus a greater overall imbalance in the global $\mathrm{N}$ budget than currently considered.

Acknowledgements. We thank the captain and crew of the R/V Coriolis II. M. Alkhatib acknowledges financial support through a GEOTOP research center scholarship. Discovery and ship-time grants from the Natural Sciences and Engineering Research Council of Canada (NSERC) to M. F. L. made this study possible.

Edited by: M. Voss

\section{References}

Alkhatib, M., Schubert, C. J., del Giorgio, P. A., Gelinas, Y., and Lehmann, M. F.: Organic matter reactivity indicators in sediments of the St. Lawrence Estuary, Estuar. Coast. Shelf S., 102103, 36-47, doi:10.1016/j.ecss.2012.03.002, 2012a.

Alkhatib, M., del Giorgio, P. A., and Lehmann, M. F.: Distribution of dissolved organic nitrogen in sediments of the Lower St. Lawrence Estuary: Links to benthic dissolved organic matter fluxes and selective organic matter degradation, Biogeosciences, in preparation, $2012 \mathrm{~b}$.

Belley, R., Archambault, P., Sundby, B., Gilbert, F., and Gagnon, J. M.: Effects of hypoxia on benthic macrofauna and bioturbation in the Estuary and Gulf of St. Lawrence, Canada, Cont. Shelf Res., 30, 1302-1313, 2010.

Bender, M., Martin, W., Hess, J., Sayles, R., Ball, L., and Lambert, C.: A whole-core squeezer for interfacial pore-water sampling, Limnol. Oceanogr., 32, 1214-1225, 1987.

Berelson, W. M., Hammond, D. E., O’Neill, D., Xu, X.-M., Chin, C., and Zukin, J.: Benthic fluxes and pore water studies from sediments of the central equatorial North Pacific - nutrient diagenesis, Geochim. Cosmochim. Ac., 54, 3001-3012, 1990.

Bourbonnais, A., Lehmann, M. F., Waniek, J. J., and Schulz-Bull, D. E.: Nitrate isotope anomalies reflect $\mathrm{N}_{2}$ fixation in the Azores Front region (subtropical NE Atlantic), J. Geophys. Res., 114, C03003, doi:10.1029/2007JC004617, 2009.

Braman, R. S. and Hendrix, S. A.: Nanogram nitrite and nitrate determination in environmental and biological materials by vana- dium (III) reduction with chemoluminescence detection, Anal. Chem., 61, 2715-2718, 1989.

Brandes, J. A. and Devol, A. H.: Isotopic fractionation of oxygen and nitrogen in coastal marine sediments, Geochim. Cosmochim. Ac., 61, 1793-1801, 1997.

Brandes, J. A. and Devol, A. H.: A global marine-fixed nitrogen isotopic budget: implications for Holocene nitrogen cycling, Global Biogeochem. Cy., 16, 1120, doi:10.1029/2001GB001856, 2002.

Cline, J. D. and Kaplan, I. R.: Isotopic fractionation of dissolved nitrate during denitrification in the eastern tropical North Pacific Ocean, Mar. Chem., 3, 271-299, 1975.

Codispoti, L. A., Brandes, J. A., Christensen, J. P., Devol, A. H., Naqvi, S. W. A., Paerl, H. W., and Yoshinari, T.: The oceanic fixed nitrogen and nitrous oxide budgets: Moving targets as we enter the anthropocene?, Sci. Mar., 65, 85-105, 2001.

Crowe, S. A., Canfield, D. E., Mucci, A., Sundby, B., and Maranger, R.: Anammox, denitrification and fixed-nitrogen removal in sediments of the Lower St. Lawrence Estuary, Biogeosciences Discuss., 8, 9503-9534, doi:10.5194/bgd-8-9503-2011, 2011.

Fennel, K., Wilkin, J., Levin, J., Moisan, J., O’Reilly, J., and Haidvogel, D.: Nitrogen cycling in the Middle Atlantic Bight: Results from a three-dimensional model and implications for the North Atlantic nitrogen budget, Glob. Biogeochem. Cy., 20, GB3007, doi:10.1029/2005GB002456, 2006.

Gilbert, D., Sundby, B., Gobeil, C., Mucci, A., and Tremblay, G.: A seventy two year record of diminishing deep water oxygen in the St Lawrence Estuary: the northwest Atlantic connection, Limnol. Oceanogr., 50, 1654-1666, 2005.

Gonfiantini, R., Stichler, W., and Rosanski, K.: Standards and intercomparison materials distributed by the IAEA for stable isotope measurements, IAEA-TECDOC-825, IAEA, Vienna, 13$31,1995$.

Granger, J., Sigman, D. M., Lehmann, M. F., and Tortell, P. D.: Nitrogen and oxygen isotope fractionation during dissimilatory nitrate reduction by denitrifying bacteria, Limnol. Oceanogr., 53, 2533-2545, 2008.

Granger, J. Prokopenko, M. G., Sigman, D. M., Mordy, C. W., Morse, Z. M., Morales, L. V., Sambrotto R. N., and Plessen, B.: Coupled nitrification-denitrification in sediment of the eastern Bering Sea Shelf leads to ${ }^{15} \mathrm{~N}$ enrichment of fixed $\mathrm{N}$ in shelf waters, J. Geophys. Res., 116, C11006, doi:10.1029/2010JC006751, 2011.

Hulth, S., Aller, R. C., Canfield, D. E., Dalsgaard, T., Engström, P., Gilbert, F., Sundbäck, K., and Thamdrup, B.: Nitrogen removal in marine environments: recent findings and future research challenges, Mar. Chem., 94, 125-145, 2005.

Knapp, A., Sigman, D., and Lipschultz, F.: N isotope composition of dissolved organic nitrogen and nitrate at the Bermuda Atlantic Time-series Study site, Global Biogeochem. Cy., 19, GB1018, doi:10.1029/2004GB002320, 2005.

Lehmann, M. F., Sigman, D. M., and Berelson, W. M.: Coupling the ${ }^{15} \mathrm{~N} /{ }^{14} \mathrm{~N}$ and ${ }^{18} \mathrm{O} /{ }^{16} \mathrm{O}$ of nitrate as a constraint on benthic nitrogen cycling, Mar. Chem., 88, 1-20, 2004.

Lehmann, M. F., Sigman, D. M., McCorkle, D. C., Brunelle, B. G., Hoffmann, S., Kienast, M., Cane, G., and Clement, J.: Origin of the deep Bering Sea nitrate deficit: Constraints from the nitrogen and oxygen isotopic composition of water column nitrate and benthic nitrate fluxes, Global Biogeochem. Cy., 19, GB4005, doi:10.1029/2005GB002508, 2005. 
Lehmann, M. F., Sigman, D. M., McCorkle, D. C., Granger, J., Hoffmann, S., Cane, G., and Brunelle, B. G.: The distribution of nitrate ${ }^{15} \mathrm{~N} /{ }^{14} \mathrm{~N}$ in marine sediments and the impact of benthic nitrogen loss on the isotopic composition of oceanic nitrate, Geochim. Cosmochim. Ac., 71, 5384-5404, 2007.

Lehmann, M. F., Barnett, B., Gélinas, Y., Gilbert, D., Maranger, R., Mucci, A., Sundby, B., and Thibodeau, B.: Aerobic respiration and hypoxia in the lower St. Lawrence Estuary: Stable isotope ratios of dissolved oxygen constrain oxygen sink partitioning, Limnol. Oceanogr., 54, 2157-2169, 2009.

Liu, K. K. and Kaplan, I. R.: The eastern tropical Pacific as a source of ${ }^{15} \mathrm{~N}$-enriched nitrate in seawater off southern California, Limnol. Oceanogr., 34, 820-830, 1989.

Lomstein, B. A., Blackburn, T. H., and Henriksin, K.: Aspects of nitrogen and carbon cycling in the northern Bering Shelf sediment. I. The significance of urea turnover in the mineralization of $\mathrm{NH}_{+}^{4}$, Mar. Ecol.-Prog. Ser., 57, 237-247, 1989.

Macko, S. A. and Estep, M. L. F.: Microbial alterations of stable nitrogen and carbon isotopic compositions of organic matter, Org. Geochem., 6, 787-790, 1984.

Mariotti, A., Germon, J. C., Hubert, P., Kaiser, P., Letolle, R., Tardieux, R., and Tardieux, P.: Experimental determination of nitrogen kinetic isotope fractionation: some principles; illustration for the denitrification and nitrification processes, Plant Soil, 62, 413-430, 1981.

Martin, W. R. and McCorkle, D. C.: Dissolved organic carbon concentrations in marine pore water determined by high temperature oxidation, Limnol. Oceanogr., 38, 1464-1479, 1993.

Middelburg, J. J., Soetaert, K., Herman, P. M. J., and Heip, C. H. R.: Denitrification in marine sediments: a model study, Global Biogeochem. Cy., 10, 661-673, 1996.

Pedersen, H., Lomstein, B. A., Isaksen, M. F., and Blackburn, T. H.: Urea production by Thjosphaera pantotropha and by anaerobic enrichment cultures from marine sediments, FEMS Microbiol. Ecol., 13, 31-36, 1993.

Prokopenko, M. G., Hammond, D. E., Berelson, W. M., Bernhard, J. M., Stott, L., and Douglas, R.: Nitrogen cycling in the sediments of Santa Barbara basin and Eastern Subtropical North Pacific: nitrogen isotopes, diagenesis and possible chemosymbiosis between two lithotrophs (Thioploca and Anammox) - "riding on a glider”, Earth Planet. Sc. Lett., 242, 186-204, 2006.
Rabalais, N., Turner, R., and Wiseman, W.: Gulf of Mexico hypoxia, "the dead zone", Annu. Rev. Ecol. Syst., 33, 235-263, 2002.

Schubert, C. J., Niggemann, J., Klockgether, G., and Ferdelman, T. G.: Chlorin Index: A new parameter for organic matter freshness in sediments, Geochem. Geophys. Geosy., 6, Q03005, doi:10.1029/2004GC000837, 2005.

Sigman D. M., Casciotti, K. L., Andreani, M., Barford, C., Galanter, M., and Bohlke, J. K.: A bacterial method for the nitrogen isotopic analysis of nitrate in seawater and freshwater, Anal. Chem., 73, 4145-4153, 2001.

Sigman, D. M., Robinson, R., Knapp, A. N., van Geen, A., McCorkle, D. C., Brandes, J. A., and Thunell, R. C.: Distinguishing between water column and sedimentary denitrification in the Santa Barbara Basin using the nitrogen isotopes of nitrate, Geochem. Geophys. Geosy., 4, 1040, doi:10.1029/2002GC000384, 2003.

Sloth, N. P., Blackburn, T. H., Hansen, L. S., Risgaard-Petersen, N., and Lomstein, B. A.: Nitrogen cycling in sediments with different organic loading, Mar. Ecol.-Prog. Ser., 116, 163-170, 1995.

Strous, M., Kuenen, J. G., and Jetten, M. S. M.: Key Physiology of Anaerobic Ammonium Oxidation, Appl. Environ. Microb., 65, 3248-3250, 1999.

Thibodeau, B., Lehmann, M. F., Kowarzyk, J., Mucci, A., Gélinas, Y., Gilbert, D., Maranger, R., and Alkhatib, M.: Benthic nutrient fluxes along the Laurentian Channel: Environmental controls and impact on the N-budget of the St. Lawrence marine system, Estuar. Coast. Shelf S., 90, 195-205, 2010.

Voss, M., Dippner, J. W., and Montoya, J. P.: Nitrogen isotope patterns in the oxygen deficient waters of the eastern tropical North Pacific Ocean, Deep-Sea Res. Pt. I, 48, 1905-1921, 2001.

Wankel, S. D., Kendall, C., and Paytan, A.: Using nitrate dual isotopic composition $\left(\delta^{15} \mathrm{~N}\right.$ and $\left.\delta^{18} \mathrm{O}\right)$ as a tool for exploring sources and cycling of nitrate in an estuarine system: Elkhorn Slough, California, J. Geophys. Res., 114, G01011, doi:10/1029/2008JG000729, 2009.

Zehr, J. and Ward, B.: Nitrogen cycling in the ocean: new perspectives on processes and paradigms, Appl. Environ. Microb., 68, 1015-1024, 2002. 